\title{
Cytogenetic Effects Induced by the Natural Pyrethrins and the Synthetic Lambda Cyhalothrin in Mice in Vivo
}

\author{
Maha A. Fahmy ${ }^{1}$ and E. F. Abdalla ${ }^{2}$ \\ ${ }^{1}$ Department of Genetics and Cytology, National Research Centre, Dokki, Cairo, Egypt \\ ${ }^{2}$ Plant Protection Department, National Research Centre, Dokki, Cairo, Egypt
}

Accepted February 5, 2001

\begin{abstract}
Summary The potential genotoxicity of the natural pyrethrins and the synthetic lambda $(\lambda)$ cyhalothrin was evaluated in mice in vivo. Single oral treatment with the doses 45, 90, $180 \mathrm{mg} \mathrm{kg}^{-1}$ b.wt. of pyrethrins and $1.25,2.5,5 \mathrm{mg} \mathrm{kg}^{-1}$ b.wt. of $\lambda$ cyhalothrin $\left(1 / 8,1 / 4,1 / 2 \mathrm{LD}_{50}\right)$ induced modest but statistically significant increase in the frequency of sister chromatid exchanges (SCE's) in bone-marrow cells. Such frequency reached $8.20 \pm 0.41$ and $8.67 \pm 0.24$ per cell after treatment with the highest tested dose of both insecticides respectively compared with $5.32 \pm 0.28$ for the control. Marked induction of SCE frequency $(12.40 \pm 0.90)$ per cell was observed after treatment with mitomycin $C$ which is used as a positive control. Single oral treatment with the doses 90 , $180 \mathrm{mg} \mathrm{kg}^{-1}$ b.wt. of pyrethrins and $1.25,2.5,5 \mathrm{mg} \mathrm{kg}^{-1}$ b.wt. of $\lambda$ cyhalothrin, induced significant increase in the percentage of chromosomal aberrations in mouse bone-marrow. With respect to germ cells only the highest tested dose of both insecticides $\left(1 / 2 \mathrm{LD}_{50}\right)$ induced a significant percentage of chromosomal aberrations in mouse spermatocytes after single oral treatment. Chromosomal aberrations were also recorded after repeated treatment. For studying sperm abnormalities mice were orally treated for 5 consecutive days with $22.5,45,90 \mathrm{mg} \mathrm{kg}^{-1}$ b.wt. of pyrethrins and $0.63,1.25$ and $2.5 \mathrm{mg} \mathrm{kg}^{-1}$ b.wt. of $\lambda$ cyhalothrin. Significant percentage of sperm abnormalities was observed after treatment with the 2 higher doses of both insecticides. In conclusion, both insecticides pyrethrins and $\lambda$ cyhalothrin induced some clastogenic effects with the high tested doses.
\end{abstract}

Key words Pyrethrins, Lambda cyhalothrin, Sister chromatid exchanges, Chromosomal aberrations, Sperm abnormalities, Genotoxicity (mouse).

The concept of utilizing certain plants possessing pesticidal activity against different species of insect, has been confirmed. The extract of pyrethrins from Chrysanthemum cinerariaefolium flowers, is a typical example as botanical insecticide. Synthetic pyrethroids are analogs of a natural chemical moiety, pyrethrins.

Synthetic pyrethroids are a group of potent insecticides that are environmentally compatible by virtue of their moderate persistence, low volatility, and poor aqueous mobility in soil (Agarwal et al. 1994). Further a wide margin of safety to mammals (Casida et al. 1983, Casida and Quistad 1995) makes them ideal insecticides for widespread use.

The natural pyrethrins and the synthetic pyrethroids are extensively used allover the world, including Egypt in order to control mosquitoes (Mutinga et al. 1992), mites (Collison et al. 1981), human head lice (Dodd 2000) and many agricultural pests (Stadler 1996):as well as veterinary and public health programes (Leahey 1985).

The genetic toxicity/mutagenicity studies on pyrethroids are rather controversial (Leahey 1985, Agarwal et al. 1994). With the use of pyrethroids steadily rising, it may be an urgent need to identify the possible adverse effects that may be associated with their use. The aim of the present work is to evaluate the possible genotoxic effects of the natural pyrethrins, and one of the synthetic pyrethroids lambda $(\lambda)$ cyhalothrin using different cytogenetic parameters in male mice in vivo. 
Materials and methods

\section{Animals}

Mature male white Swiss mice (9-12 weeks old, weighing 25-30g) were used in all experiments. The animals were obtained from a closed random-bred colony at the National Research Centre, maintained under controlled conditions of temperature and humidity and receiving food and water ad libitum.

\section{Chemicals}

Two insecticides were used in the present study.

I. Pyrethrins: Natural extract of pyrethrum flowers, produced by Scientific Chemical Industries. Firm Scien Co. Egypt, $60 \%$ active ingredients. This crude extract is fully identified as esters of 3 alcohols with chrysanthemic and pyrethric acids as shown in Fig. 1.

II. Lambda cyhalothrin: Synthetic pyrethroid insecticide, trade name "Karate" (Fig. 2). CAS chemical name: $(\mathrm{R}+\mathrm{S})-\alpha$-cyano-3-(phenoxyphenyl)methyl-(1S+1R)-cis-3(z-2-chloro-3,3,3trifluoroprop-1-enyl)-2,2-dimethyl-cyclopropane-carboxylate, CASRN 91465-08-06 was from Zeneca Agrochemicals. England (2.5\%).

\section{Treatment and cytological preparations}

Sister chromatid exchange: Three different doses were tested $45,90,180 \mathrm{mg} \mathrm{kg}^{-1}$ b.wt. for pyrethrins (dissolved in corn oil) and $1.25,2.5,5 \mathrm{mg} \mathrm{kg}^{-1}$ b.wt. for $\lambda$ cyhalothrin (dissolved in distilled water). Such doses are correspondent to $1 / 8,1 / 4,1 / 2$ of the experimental $\mathrm{LD}_{50}$ of both insecticides respectively. The method described by Allen (1982) for conducting in vivo sister chromatid exchange was applied with modifications. 5Bromodeoxyuridin (BrdU, Sigma) tablets weighing $55 \pm 5 \mathrm{mg}$ were placed subcutaneously for $21 \mathrm{~h}$. The mice were orally treated by gavage with the insecticides $8 \mathrm{~h}$ after BrdU implantation, and were injected with colchicine $(0.6 \mathrm{mg} / \mathrm{kg}) 2 \mathrm{~h}$ prior to killing. Bone-marrow cells were obtained in $\mathrm{KCl} 0.075 \mathrm{M}$ at $37^{\circ} \mathrm{C}$, keeping the cells $20 \mathrm{~min}$ at the same temperature then fixed in methanol-acetic acid solution $3: 1$. Smears were prepared and stained with fluorescence plus Giemsa method of Goto et al. (1978). Five animals were taken for each treatment and at least 30 well spread metaphases per animal were examined microscopically for SCE's.

Chromosomal aberration: For bone-marrow or spermatocytes, groups of 5 animals were orally treated by gavage with a single dose of $22.5,45,90,180 \mathrm{mg} \mathrm{kg}^{-1} \mathrm{~b}$.wt. of pyrethrins or with $0.63,1.25,2.5,5 \mathrm{mg} \mathrm{kg}^{-1}$ b.wt. of $\lambda \mathrm{cy}$ halothrin. Samples were taken $24 \mathrm{~h}$ post treatment. For subacute treatment, mice were orally treated by gavage for 5 consecutive days at the dose levels of $22.5,45,90 \mathrm{mg} \mathrm{kg}^{-1}$ b.wt. for pyrethrins and $0.63,1.25,2.5 \mathrm{mg} \mathrm{kg}^{-1}$ b.wt. for

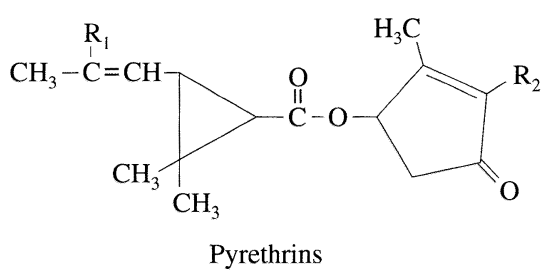

$\begin{array}{lll} & \mathrm{R}_{1} & \mathrm{R}_{2} \\ \text { Pyrethrin I } & \mathrm{CH}_{3} & \mathrm{CH}_{2} \mathrm{CH}=\mathrm{CHCH}=\mathrm{CH}_{2} \\ \text { Jasmolin I } & \mathrm{CH}_{3} & \mathrm{CH}_{2} \mathrm{CH}=\mathrm{CHCH}_{2} \mathrm{CH}_{3} \\ \text { Cinerin I } & \mathrm{CH}_{3} & \mathrm{CH}_{2} \mathrm{CH}=\mathrm{CHCH}_{3} \\ \text { Pyrethrin II } & \mathrm{COOCH}_{3} & \mathrm{CH}_{2} \mathrm{CH}=\mathrm{CHCH}=\mathrm{CH}_{2} \\ \text { Jasmolin II } & \mathrm{COOCH}_{3} & \mathrm{CH}_{2} \mathrm{CH}=\mathrm{CHCH}_{2} \mathrm{CH}_{3} \\ \text { Cinerin II } & \mathrm{COOCH}_{3} & \mathrm{CH}_{2} \mathrm{CH}=\mathrm{CHCH}_{3}\end{array}$

Fig. 1. Crude extract of pyrethrins.

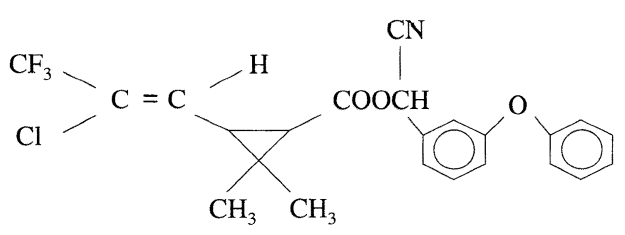

Fig. 2. Structure of the pyrethroid insecticide lambda cyhalothrin $\mathrm{C}_{23} \mathrm{H}_{19} \mathrm{ClF}_{3} \mathrm{NO}_{3}$. 
$\lambda$ cyhalothrin. Samples were taken $24 \mathrm{~h}$ after the last treatment. Bone-marrow chromosomes were prepared according to the method of Yosida and Amano (1965). Chromosomes of diakinesis-MI spermatocytes were prepared according to the air drying technique of Evans et al. (1964). Slides were stained with 7\% Giemsa in phosphate buffer ( $\mathrm{pH}$ 6.8). At least 75-100 well spread metaphases were analyzed per each animal to score different types of aberrations.

Sperm-shape abnormalities: Groups of animals (5/group) were orally treated by gavage for 5 consecutive days at the dose levels of $22.5,45,90 \mathrm{mg} \mathrm{kg}^{-1} \mathrm{~b}$.wt./day for pyrethrins and $0.63,1.25$, $2.5 \mathrm{mg} \mathrm{kg}^{-1}$ b.wt./day for $\lambda$ cyhalothrin. Animals were killed on the 35 th day after administering the first dose. Sperms were prepared according to the recommended method of Wyrobek and Bruce (1978). Mice were killed by cervical dislocation. The epididymides were excised and minced in $2 \mathrm{ml}$ physiological saline and filtered to exclude large tissue fragments. Smears were prepared and stained with $1 \%$ Eosin Y. Thousand sperms were counted for each animal to score different types of sperm abnormalities (head-tail).

For all the above experiments, control groups (non-treated and corn oil) were run alongside the test material in addition to the positive control group treated intraperitoneally with $1 \mathrm{mg} \mathrm{kg}^{-1} \mathrm{~b}$.wt. mitomycin C as recommended by Preston et al. (1987). It is acceptable that a positive control may be administered by a route different from the test agent and sampled at only a single time (Hayashi et al. 1994).

\section{Statistical analysis}

In all experiments the resulting data between groups were statistically compared using Fisher's least significant differences and Duncan's multiple range test. The significance of the incidence of abnormalities in experimental versus control data was calculated using the t-test.

\section{Results and discussion}

The results of sister chromatid exchange (SCE) analysis in bone-marrow chromosomes after oral treatment with pyrethrins and $\lambda$ cyhalothrin are summerized in Table 1 and Fig. 3a, b. The results reveal modest induction with statistical significance at all the tested concentration levels $(1 / 8$, $\left.1 / 4,1 / 2 \mathrm{LD}_{50}\right)$ as compared to the solvent control group. The frequency of the induced SCE's increased as the dose was raised. Further the SCE's induced by $\lambda$ cyhalothrin were slightly higher in

Table 1. Frequency of sister chromatid exchanges (SCE's) in mouse bone-marrow cells after oral administration of pyrethrins and $\lambda$ cyhalothrin

\begin{tabular}{|c|c|c|c|c|}
\hline $\begin{array}{l}\text { Treatment } \\
\text { and doses }\end{array}$ & Mice No. & $\begin{array}{l}\text { No. of examined } \\
\text { metaphases with } \\
\text { differentiation }\end{array}$ & SCE's No. & SCE's/cell mean \pm S.E. \\
\hline I Control (corn-oil) & 5 & 150 & 798 & $5.32 \pm 0.28$ \\
\hline \multicolumn{5}{|l|}{ II Pyrethrins } \\
\hline $45 \mathrm{mg} \mathrm{kg}^{-1}$ b.wt. & 5 & 150 & 957 & $6.38 \pm 0.30 *$ \\
\hline $90 \mathrm{mg} \mathrm{kg}^{-1}$ b.wt. & 5 & 150 & 1065 & $7.10 \pm 0.23 *$ \\
\hline $180 \mathrm{mg} \mathrm{kg}^{-1}$ b.wt. & 5 & 150 & 1230 & $8.20 \pm 0.41 * *$ \\
\hline III Control (non-treated) & 5 & 150 & 768 & $5.12 \pm 0.28$ \\
\hline \multicolumn{5}{|l|}{ IV $\lambda$ Cyhalothrin } \\
\hline $1.25 \mathrm{mg} \mathrm{kg}^{-1}$ b.wt. & 5 & 150 & 1125 & $7.50 \pm 0.26^{*}$ \\
\hline $2.5 \mathrm{mg} \mathrm{kg}^{-1}$ b.wt. & 5 & 150 & 1207 & $8.05 \pm 0.40 *$ \\
\hline $5 \mathrm{mg} \mathrm{kg}^{-1}$ b.wt. & 5 & 150 & 1301 & $8.67 \pm 0.24 * *$ \\
\hline \multicolumn{5}{|l|}{ V Mitomycin C (positive control) } \\
\hline $1 \mathrm{mg} \mathrm{kg}^{-1}$ b.wt. & 5 & 150 & 1860 & $12.40 \pm 0.90^{* * *}$ \\
\hline
\end{tabular}

* Significant at 0.05 level, ** significant at 0.01 level, $* * *$ significant at 0.001 level (t-test). 


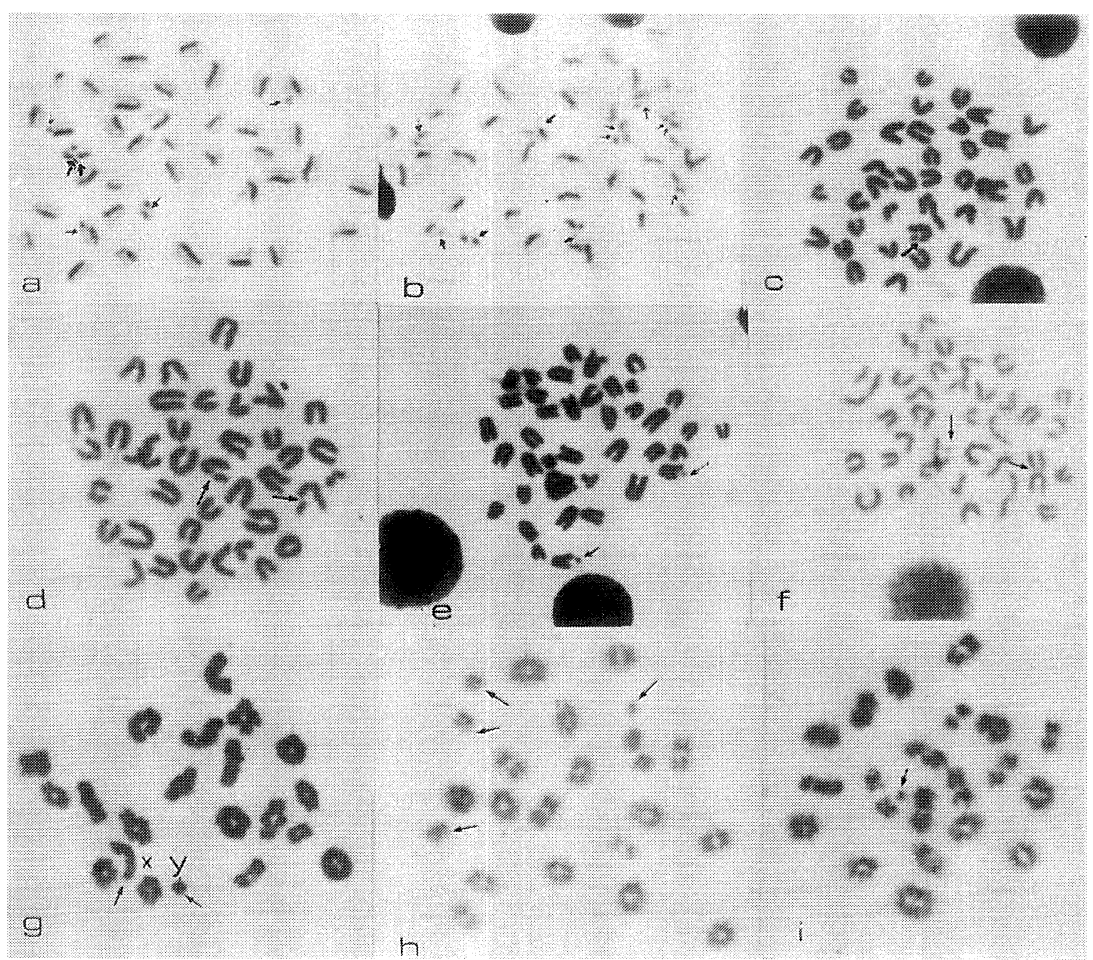

Fig. 3. Metaphases from mouse bone-marrow showing: a-b) SCE's, c) chromatid gap, d) chromatid gap and chromatid break, e) fragments, f) fragment and robertsonian translocation. Metaphases from mouse spermatocytes showing: g) $\mathrm{x}-\mathrm{y}$ univalent, $\mathrm{h}$ ) autosomal univalent and $\mathrm{x}-\mathrm{y}$ univalent, i) fragment induced after oral treatment with pyrethrins and $\lambda$ cyhalothrin.

frequency than that induced by pyrethrins. Such frequency of SCE's reached $8.20 \pm 0.41$ and $8.67 \pm 0.24$ per cell $(\mathrm{p}<0.01)$ after treatment with the highest tested dose of both insecticides respectively compared with $5.32 \pm 0.28$ for the control. Marked increase in the frequency of SCE's (12.40 \pm 0.90$)$ per cell was observed after intraperitoneal treatment with $1 \mathrm{mg} \mathrm{kg}^{-1}$ b.wt. mitomycin $\mathrm{C}$ which is an alkylating mutagen used as a positive control. This result is in agreement with the previous reports concerning the induction of SCE's by pyrethroids in mouse bone-marrow cells (Amer et al. 1993, Chauhan et al. 1997), in human lymphocyte cultures (Puig et al. 1989, Dolara et al. 1992), in CHO cells (Caballo et al. 1992). Other pyrethroids such as supermethrin and deltamethrin give negative results (Dianovsky and Sivikova 1995, Villarini et al. 1998).

With respect to chromosomal aberrations in bone-marrow cells. Table 2 shows that single oral treatment with the doses $22.5,45 \mathrm{mg} \mathrm{kg}^{-1}$ b.wt. of pyrethrins and $0.63 \mathrm{mg} \mathrm{kg}^{-1}$ b.wt. $\lambda$ cyhalothrin had no significant effect compared with the control groups. Significant increase in the incidence of chromosomal aberrations was observed at the doses $90,180 \mathrm{mg} \mathrm{kg}^{-1}$ b.wt. of pyrethrins and 1.25 , $2.5,5 \mathrm{mg} \mathrm{kg}^{-1}$ b.wt. $\lambda$ cyhalothrin. The percentage of the induced aberrations reached $7.3 \pm 0.6$ and $8.3 \pm 0.7(\mathrm{p}<0.01)$ after treatment with the highest dose $\left(1 / 2 \mathrm{LD}_{50}\right)$ of pyrethrins and $\lambda$ cyhalothrin respectively compared with $2.3 \pm 0.5$ for control. Such values are greatly lower than that induced by the positive control mitomycin C (21.3 \pm 0.9$)$, which may indicate a weak clastogenic effect of both insecticides. Moreover repeated treatment ( 5 consecutive days) concerning different doses of both insecticides show slight increase in the percentage of chromosomal aberrations (range 1.2-2.8\%) over that of the single dose treatment. This may be explained by the fact that when pyrethroids are 


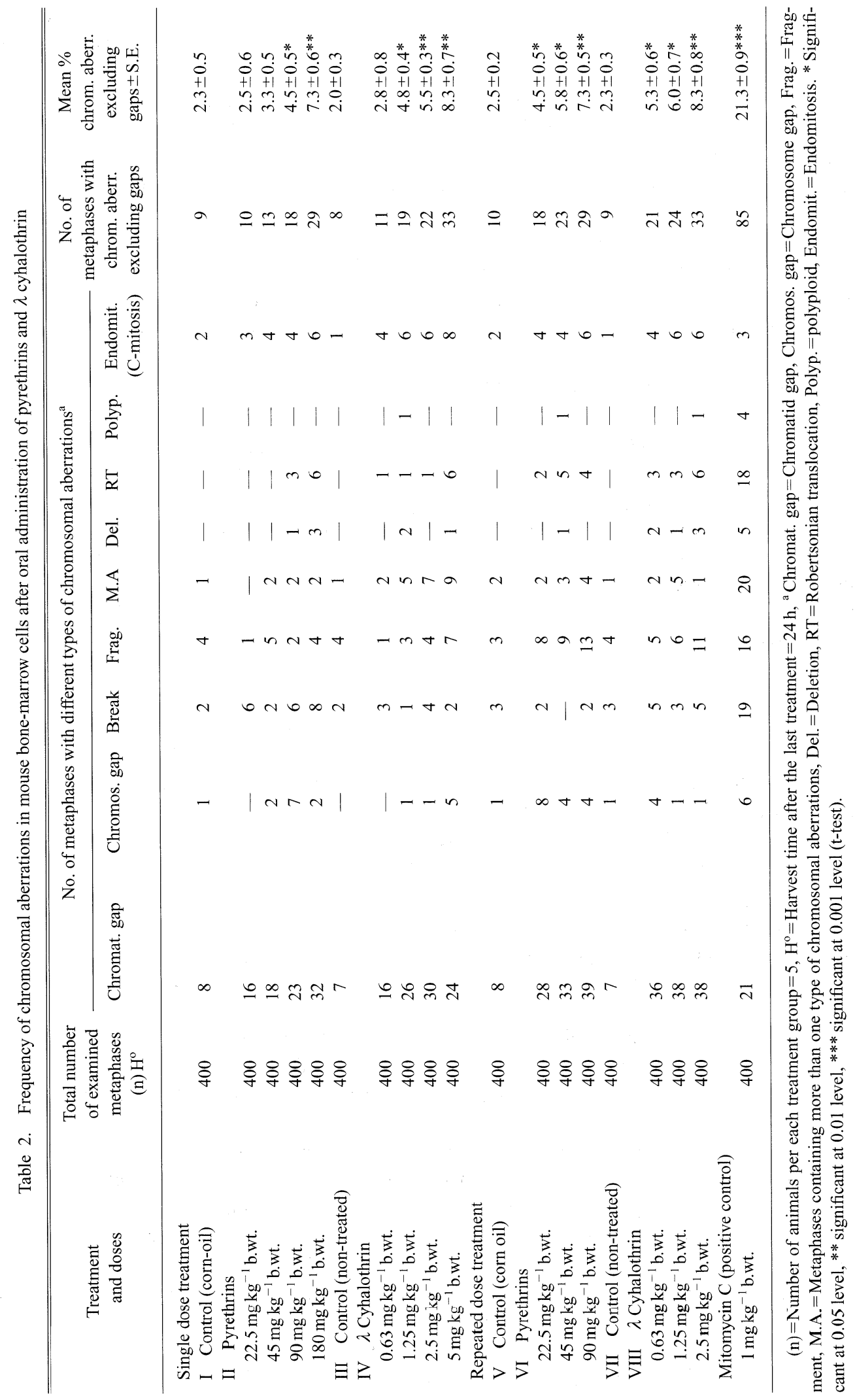


orally administrated to mammals, they are converted by hydrolytic or oxidative attack to polar metabolites, which are then eliminated unchanged or as conjugates in the faeces or urine (Litchfield 1985).

Concerning the different types of the induced aberrations (Fig. 3c-f), gaps were found to be the most sensitive type induced after treatment with the 2 pyrethroids. The importance of recording gaps in assessing the mutagenic potential of compounds has been controversial and can be considered as a separate category of damage (Brøgger 1982). In the present results, gaps were recorded but not included in the total aberrations. Breaks, fragments, deletions, translocations were observed. The aberrations were mainly of chromatid type. Numerical chromosomal aberrations in the form of endomitosis (endomitotic reduplication) were recorded in all treated groups. Endomitotic reduplication is specialized process of doubling the chromosome material with the tendency of cells to pass from G2 to the next S-phase without undergoing cell division. Mitotic spindle disturbances are considered important to this process (Dean and Danford 1984). Agarwal et al. (1994) reported that other pyrethroids such as deltamethrin induced endomitotic reduplication in rat bone-marrow cells.

The genetic toxicity/mutagenicity studies concerning the natural pyrethrins or the synthetic pyrethroids have produced controversial result depending on the compound itself or the assay used. The pyrethrum extract was reported to give negative results, in the Ames test using Salmonella typhimurium, in chromosomal aberrations in CHO cells and in DNA synthesis in rat primary hepatocytes (Williams 1973). Further some pyrethroids were reported to be scarcely clastogenic in a variety of mammalian assays (FOA 1981, Polakova and Vargova 1983, Leahey 1985). On the contrary other pyrethroids were reported to be mutagenic in rodent bone-marrow (Chatterjee et al. 1982, Amer and Aboul-Ela 1985, Pati and Bhunya 1989, Amer et al. 1993, Agarwal et al. 1994), human peripheral lymphocyte cultures (Puig et al. 1989, Surralles et al. 1990), and in aquatic organisms (Campana et al. 1999).

The induction of chromosomal aberrations in mouse spermatocytes was also studied (Table 3). Single oral treatment with different doses of both insecticides had no significant effect except with the highest tested dose $\left(1 / 2 \mathrm{LD}_{50}\right)$ where the percentage was significant at $\mathrm{P}<0.05$. Such percentage reached $8.60 \pm 0.47$ and $9.20 \pm 0.52$ after treatment with pyrethrins and $\lambda$ cyhalothrin respectively compared with $5.25 \pm 0.48$ for the control. Mitomycin C showed higher percentage of chromosomal aberrations (19.75 \pm 0.60$)$ in mouse spermatocytes than the 2 insecticides. Moreover groups of mice treated for 5 consecutive days with the different doses show that the incidence of chromosomal aberrations did not exceed two fold increase over that of the groups with single dose treatment. After treatment with different doses of both insecticides, structural aberrations (Fig. $3 g-i$ ) were the main types observed in mouse spermatocytes. Autosomal and qouesomal univalents were increased. However, the latter univalents were much more frequent. Breaks, fragments, gaps, and translocations in the form of chain IV were also observed. It should be mentioned in this context that the genotoxic effect of the tested pyrethroids in germ cells was lower than that induced by other insecticides e.g. organophosphorous (Fahmy and Abdalla 1998) and carbamate (Farghaly 1997), also chemical mutagens (Fahmy and Aly 2000) and heavy metals (Fahmy 1999) which induce great damage to germ cells.

Chromosomal abnormalities in mouse spermatocytes are expected to show their effect on sperm morphology (Devi and Reddy 1985). Although not widely used in genotoxicity studies, the sperm morphology test appears to be sensitive because sperm shapes are known to be genetically controlled by numerous autosomal and sex linked genes (Krzanowska 1976). The regular process of sperm development involves the activity of several genes and the formation of normal sperm heads involving intricate synchronous morphological and biochemical steps (Rattner 1972). A statistically significant increase in the percentage of morphologically abnormal sperm occurred in the mice treated with 5 consecutive doses of pyrethrins at $45,90 \mathrm{mg} \mathrm{kg}^{-1}$ b.wt. and $\lambda$ cyhalothrin at 1.25 , $2.5 \mathrm{mg} \mathrm{kg}^{-1}$ b.wt. (Table 4, Fig. 4). Such percentage reached $6.80 \pm 0.82$ and $7.36 \pm 0.39$ after treat- 


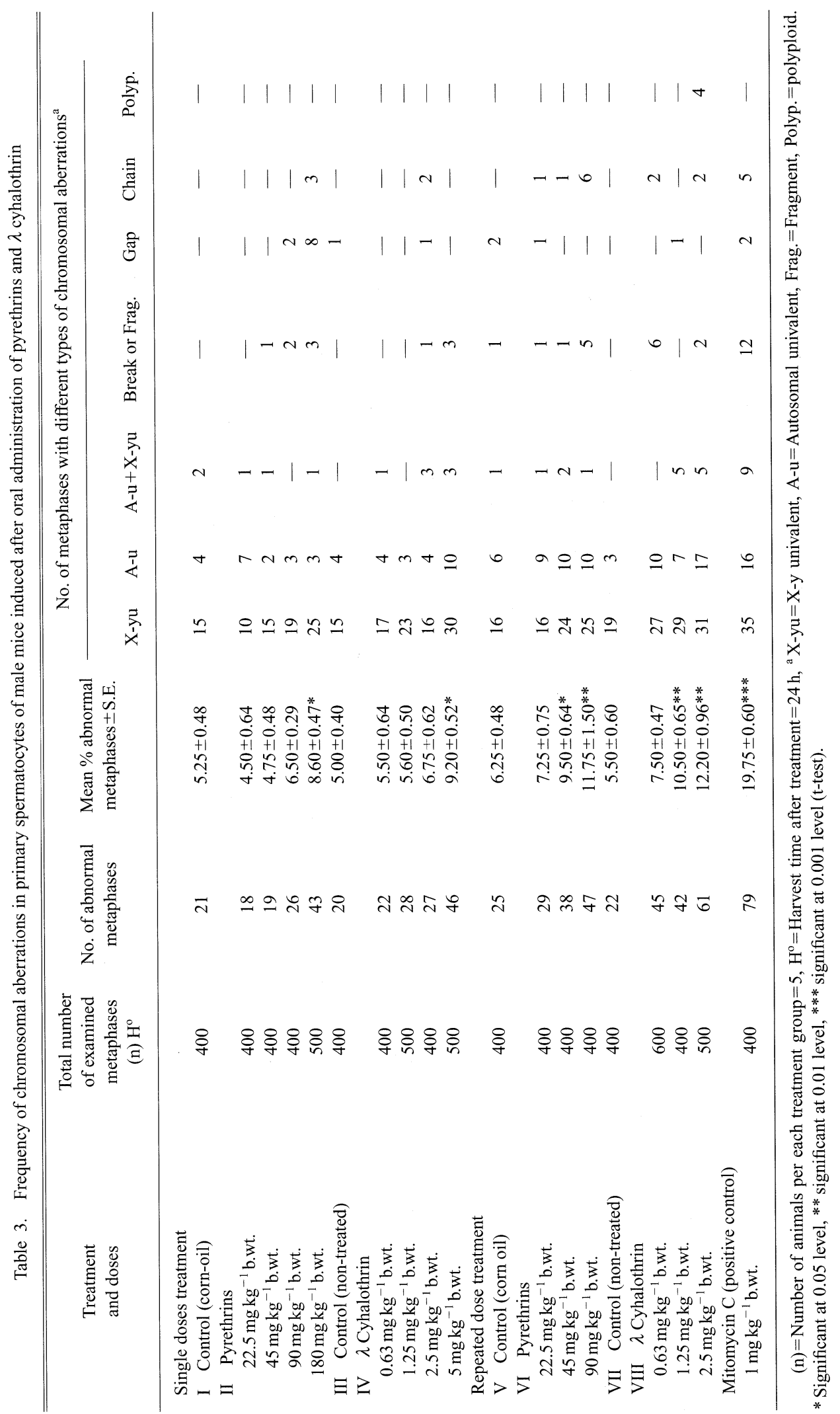




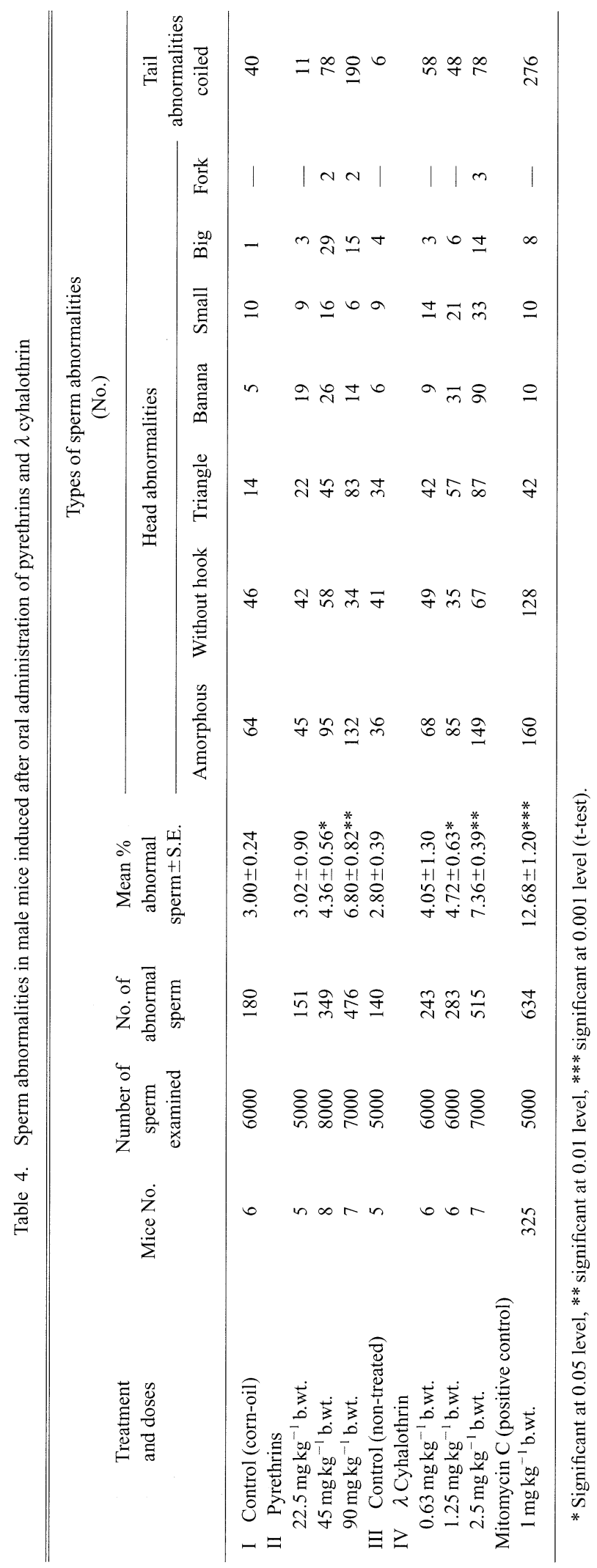




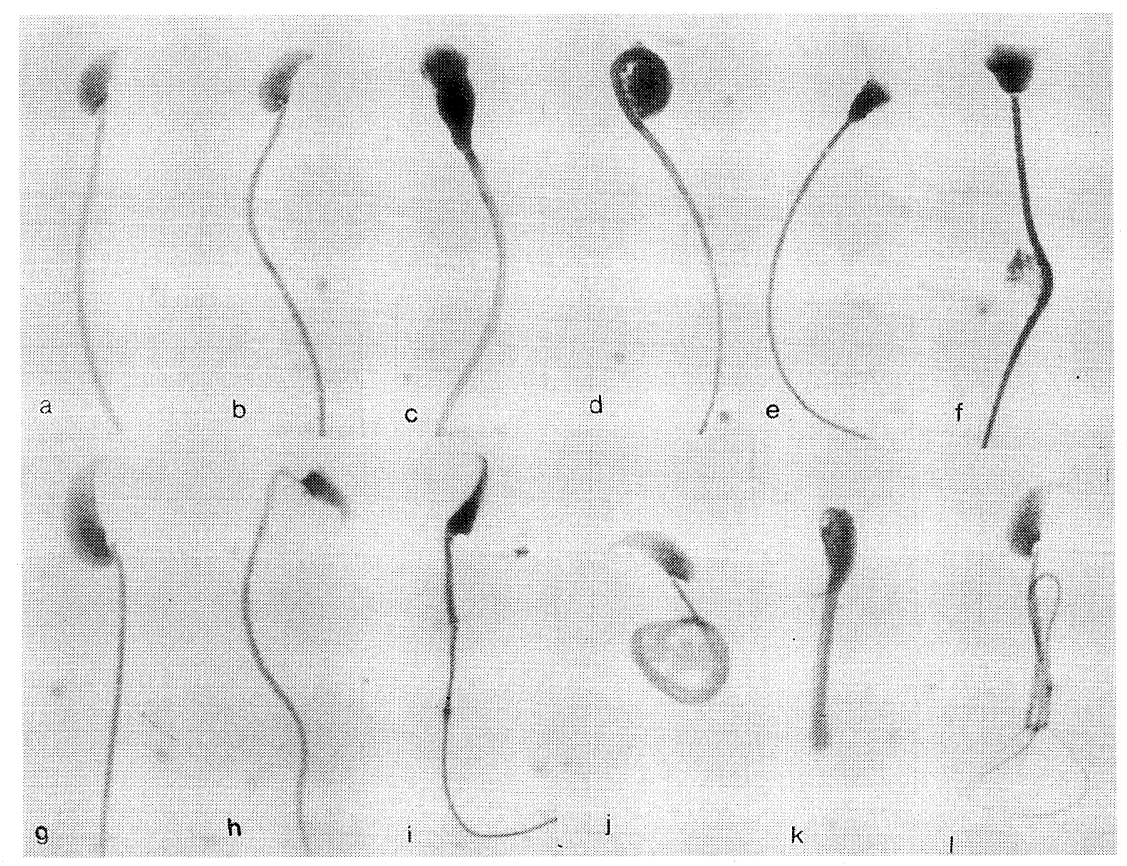

Fig. 4. Different types of sperm abnormalities induced in male mice after oral treatment with pyrethrins and $\lambda$ cyhalothrin: a) normal sperm, b) without hook, c-e) amorphous, f) triangle, g) big head, h) small head, i) banana, $\mathrm{j}-1$ ) coiled tail.

ment with the highest tested dose of both insecticides respectively compared with $3.00 \pm 0.24$ for the control. Further marked increase in the incidence of sperm abnormalities was observed after treatment with mitomycin C $(12.68 \pm 1.20)$.

It could be concluded that the natural pyrethrins and the synthetic $\lambda$ cyhalothrin induced some clastogenic effects with the high tested doses but the effect was greatly lower than that induced by mitomycin $\mathrm{C}$.

\section{References}

Agarwal, D. K., Chauhan, L. K. S., Gupta, S. K. and Sundararaman, V. 1994. Cytogenetic effects of deltamethrin on rat bone-marrow. Mut. Res. 311: 133-138.

Allen, J. W. 1982. A Method for Conducting in vivo Induction Analysis in Mice. Genetic Toxicology Division, U. S. Environmental Protection Agency, Research Triangle Park, North Carolina, 27711.

Amer, S. M. and Aboul-Ela, E. I. 1985. Cytogenetic effects of pesticide: Induction of micronuclei in mouse bone marrow by the insecticides cypermethrin and rotenone. Mut. Res. 55: 135-142.

- Ibrahim, A. S. and El-Sherbeny, K. M. 1993. Induction of chromosomal aberrations and sister chromatid exchange in vivo and in vitro by the insecticide cypermethrin. J. App. Toxicol. 13: 341-345.

Brøgger, A. 1982. The chromatid gap a useful parameter in genotoxicology? Cytogenet. Cell Genet. 33: 14-19.

Caballo, C., Herrera, A., Barrueco, C., Santa-Maria, A., Sanz, F. and Pena, E. 1992. Analysis of cytogenetic damage induced in CHO cells by the pyrethroid insecticide fenvalerate. Teratog. Carcinog. Mutagen 12: 243-249.

Campana, M. A., Panzeri, A. M., Moreno, V. J. and Dulout, F. N. 1999. Genotoxic evaluation of the pyrethroid lambda-cyhalothrin using the micronucleus test in erythrocytes of the fish Cheirodon interruptus. Mut. Res. 438: 155-161.

Casida, J. E., Gammon, D. W., Glickman, A. H. and Lawrence, L. J. 1983. Mechanisms of selective action of pyrethroids. Ann. Rev. Pharmacol. Toxicol. 23: 413-438.

- and Quistad. 1995. Pyrethrum Flowers, Production, Chemistry, Toxicology and Uses. Oxford University Press, New York.

Chatterjee, K. K., Talukdar, G. and Sharma, A. 1982. Effects of synthetic pyrethroids in mammalian chromosomes. I. Sum- 
icidin. Mut. Res. 105: 102-106.

Chauhan, L. K., Agarwal, D. K. and Sundararaman, V. 1997. In vivo induction of sister chromatid exchange in mouse bone marrow following oral exposure to commercial formulations of alpha-cynopyrethroids. Toxicol. Lett. 93: $153-157$

Collison, C. H., Danka, R. G. and Kennell, D. R. 1981. An evaluation of permethrin, carbaryl and amitraz for the control of northern fowl mites on caged chickens. Poult. Sci. 6: 1812-1817.

Dean, B. J. and Danford, N. 1984. Assays for the Detection of Chemically Induced Chromosomal Damage in Cultured Mammalian Cells. In: Venitt, S. and Perry, J. M. (eds.). Mutagenicity Testing.

Devi, K. R. and Reddy, P. P. 1985. Bisazir induced cytogenetic damage and sperm head abnormalities in mice. IRCS Med. Sci. 13: $1245-1246$.

Dianovsky, J. and Sivikova, K. 1995. In vivo and in vitro cytogenetic effect of supermethrin. Biomed. Environ. Sci. 8: 359-366.

Dodd, C. S. 2000. Interventions for treating headlice cochrane. Database Syst. Rev. 2: CD 001165.

Dolara, P., Salvadori, M., Capobianco, T. and Torricelli, F. 1992. Sister-chromatid exchanges in human lymphocytes induced by dimethoate, omethoate, deltamethrin, benomyl and their mixture. Mut. Res. 283: 113-118.

Evans, E. P., Breckon, G. and Ford, C. E. 1964. An air drying method for meiotic preparation from mammalian testes. Cytogenetics 3: 289 .

Fahmy, M. A. 1999. Lead acetate genotoxicity in mice. Cytologia 64: 357-365.

— and Abdalla, E. F. 1998. Genotoxicity evaluation of buprofezin, petroleum oil and profenofos in somatic and germ cells of male mice. App. Toxicol. 18: 301-305.

— and Aly, F. A. 2000. Effect of vitamin C against the genotoxicity induced by N-nitrosodiethanolamine in mice in vivo test system. Cytologia 65: 243-252.

Farghaly, A. A. 1997. Studies on the genotoxic effect of the insecticide "sevin" on the mouse. B. SC. Thesis, Department of Zoology, Faculty of Scince Cairo University.

FOA 1981. Pesticide Residues. In: Food-1980 Evaluations FAO Plant Production and Protection Paper26 Suppl. Food and Agricultural organization of the United Nations, Rome.

Goto, K., Maeda, S., Kano, Y. and Sugiyama, T. 1978. Factors involved in differential Giemsa staining of sister chromatids. Chromosoma 66: 351-359.

Hayashi, M., Tice, R. R., MacGregar, J. T., Anderson, D., Blakey, D. H., Irsh-Volders, M., Oleson, Jr., F. B., Pacchierotti, F., Romagna, F., Shimada, H., Sutou, S. and Vannier, B. 1994. In vivo rodent erythrocyte micronucleus assay. Mut. Res. 312: 293-304.

Krzanowska, H. 1976. Inheritance of sperm head abnormality types in mice and the role of the Y chromosome. Genetic. Res. 28: 189-198.

Leahey, J. P. 1985. The Pyrethroid Insecticides. Taylor and Francis, London.

Litchfield, M. H. 1985. Toxicity to Mammals. In: Leahey, J. P. (ed.). The Pyrethroid Insecticides. Taylor and Francis, London. pp. $99-150$.

Mutinga, M. J., Mutero, C. M., Basimike, M. and Nginda, A. M. 1992. The use of permethrin-impregnated wale Cloth (MBU cloth) for the control of vectors of malaria and leishamaniases in kenya-1. Effect on mosquito populations. Insect Sci. Applic. 13: 151-161.

Pati, P. C. and Bhunya, S. P. 1989. Cytogenetic effects of fenvalerate in mammalian in vivo test system. Mut. Res. 222: $149-154$.

Polakova, H. and Vargova, M. 1983. Evaluation of the mutagenic effects of decamethrin: Cytogenetic analysis of bone-marrow. Mut. Res. 120: 167-171.

Preston, R. J., Dean, B. D., Galloway, S., Holden, H., McFee, A. F. and Shelky, M. 1987. Mammalian in vivo cytogenetic assays: analysis of chromosome aberrations in bone-marrow cells. Mut. Res. 189: 157-165.

Puig, M., Carbonell, E., Xamena, N., Creus, A. and Marcos, R. 1989. Analysis of cytogenetic damage induced in cultured human lymphocytes by the pyrethroid insecticides cypermethrin and fenvalerate Mutagenests 4: 72-74.

Rattner, J. B. 1972. Nuclear shoping in marsupial spermatids. J. Ultrastruct. Res. 40: 496.

Stadler, T. 1996. Monitoring susceptibility to selected insecticides in Spodoptera frugiperda and Spodoptera latifascia populations two main cotton pests in Northern Argentina. Resistant pest. Mang. 8: 14-16.

Surralles, J., Carbonella, E., Puig, M., Xamena, N., Creus, A. and Marcos, R. 1990. Induction of mitotic micronuclei by the pyrethroid insecticide fenvalerate in cultured human lymphocytes. Toxicol. Lett. 54: 151-155.

Villarini, M., Moretti, M., Pasquini, R., Scassellati-Sforzolini, G., Fatigoni, C., Marcarelli, M., Monarco, S. and Rodriguez, A. V. 1998. Toxicology 130: 129-139.

Williams, C. H. 1973. Tests for Possible, Teratogenic, Carcinogenic, Mutagenic, and Allergenic Effects of Pyrethrum. In: Casida, J. E. (ed.). The Natural Insecticide. Academic press, New York. pp. 167-176.

Wyrobek, A. J. and Bruce, W. R. 1978. The induction of sperm-shape abnormalities in mice and humans. In: Hollaender, A. and de Serres, F. J. (eds.). Chemical Mutagens, Vol. 5: Principles and Methods for their Detection. Plenum, New 
York. pp. 257-285.

Yosida, T. H. and Amano, K. 1965. Autosomal polymorphism in laboratory bred and wild Norway rats, Rattus norvegicus found in Misima. Chromosoma 16: 658-667. 